\title{
Dijital Boşanmaya İlişkin Güncel Düzenlemeler: Farklı Ülke Uygulamaları*
}

\author{
Current Regulations on Digital Divorce: Examples \\ from Different Countries
}

Seldă̆ Güneş Peschke**

$\ddot{O} z \bullet$ Teknolojinin gelişmesiyle birlikte, hukukî düzenlemeler de toplumun ihtiyaçları çerçevesinde gelişmeye ve değişmeye başlamıştır. Teknoloji ile hukukun etkileşiminde, artık bir çok işlem online olarak internetten yapılabilmektedir. Yaşadığımız dijital çağda, hukuksal gelişmeler de teknolojiyi izlemek zorundadır. Son yıllarda, aile hukukuna ilişkin bazı işlemler de internet üzerinden online yapılmaya başlanmıştır. Henüz Türkiye'de kabul edilmemekle birlikte, bunların en çarpıcı örneklerinden bir tanesi olan, online boşanma veya orijinal adıyla "Digital Divorce" (dijital boşanma), Hollanda ve Birleşik Krallık'ta uygulamaya girmiştir.

Dijital boşanma ile eşlerin bir araya gelmeden kısa ve ucuz bir maliyetle sonuca ulaşması amaçlanmıştır. Bu tür boşanmalarda, eşler kendi rızasıyla boşanmalarına hızlı ve ucuz bir şekilde, fakat bir duruşmada bir araya gelmeden karar verirler. Dijital boşanma koşulları bu anlamda birçok ülkede halen kullanılan ve o ülkenin geleneklerine ve yasal düzenlemelerine göre bazı farklılıklar gösteren anlaşmalı boşanma koşullarına benzemektedir. Bu tebliğde, Avrupa ülkelerinde

* İstanbul Ticaret Üniversitesi Kadın ve Aile Uygulama ve Araştırma Merkezi ile Kadın ve Demokrasi Derneği (KADEM) ortaklığında, 8 Mart 2018 tarihinde düzenlenen "4. Toplumsal Cinsiyet Adaleti: Boşanma" kongresinde sunulmuştur.

** Ankara Yıldırım Beyazıt Üniversitesi Hukuk Fakültesi Öğretim Üyesi, Orcid ID: 0000-0003-3679-6525.

\footnotetext{
Başvuru: 28 Mart 2018

Kabul: 18 Mayıs 2018

DOI: 10.21798/kadem.2018141985
}

Copyright (c) 2018 • KADEM Kadın ve Demokrasi Derneği kadinarastirmalari.kadem.org.tr

ISSN 2149-6374 • Haziran 2018 • 4 (1) • 121 - 146 
ve Türkiye'de anlaşmalı boşanmaya ilişkin düzenlemeler ve unsurları genel hatlarıyla ele alınmış ve dijital boşanma ile karşılaştırmalı bir şekilde incelenmiştir.

Anahtar Kelimeler: Boşanma, Dijital Boşanma, Anlaşmalı Boşanma, Boşanma Hukuku, Karşılaştırmalı Hukuk.

\begin{abstract}
Technological developments have led to the transformation of the way through which law is implemented to address the needs of society. In the age of digitization, the internet has become a key platform for the practice of law. It has progressed to such a point that legal transactions concerning family law are now being conducted via the internet. Online divorce, or in other words digital divorce, is in use in the Netherlands and the U.K., even though the practice is not accepted in Turkey or other European countries as yet. Within digital divorce, agreed spouses can split their paths very fast and cheaply, even without coming face to face. In this sense, online divorce seems very similar to mutual divorce which, despite superficial differences based on tradition and legal regulations, is in use in many countries. This study will present a comparative analysis of the conditions of mutual divorce and digital divorce in line with the legal developments across various countries.
\end{abstract}

Keywords: Divorce, Digital Divorce, Mutual Divorce, Divorce Law, Comparative Law.

\title{
Giriş
}

Teknolojinin gelişmesiyle birlikte, hukukî düzenlemeler de toplumun ihtiyaçları çerçevesinde gelişmeye ve değişmeye başlamıştır. Teknoloji ile hukukun etkileşiminde, artık bir çok işlemin online olarak internetten yapılabildiği günümüzde, hukuksal gelişmeler de teknolojiyi izlemek zorunda kalmıştır. Bunun sonucunda yeni bir kavram ortaya çıkmıştır: Legaltech. Hukuk büroları artık teknolojinin imkanlarını hukuk alanında da kendi lehlerine kullanmaktadırlar.

Son yıllarda hukuk ve teknoloji konusunda yapılan çalışmaların sayısındaki artış da bunun bir göstergesidir. Günümüzde çıkarılan kanunların bir kısmı, teknolojik gelişmeler sonucunda ortaya çıkabilecek belirsizliklere çözüm bulmak amacıyla yürürlüğe konmaktadır. Yani, teknolojideki anlık değişiklikler, etkilerini hukuk alanında da göstermektedir. Bir çok işlemin online yapılabildiği 
günümüzde, aile hukukuna ilişkin bazı işlemlerin ve hatta davaların usulünde de değişikliğe ve yeniliğe gidilmeye başlanmıştır. $\mathrm{Bu}$ bağlamda, dijital boşanma da teknoloji ile hukuku bir araya getiren uygulamalardan biri olarak karşımıza çıkmaktadır.

\section{I. "Boşanma"nın Tanımı ve Farklı Ülkelerdeki Hukukî Uygulamalar}

\section{A. Genel Olarak}

Evlenme Türk Medenî Kanunu'nda tanımlanmamakla birlikte, tam ve sürekli bir hayat ortaklı̆g ayrı iki kişinin yaptıkları bir sözleşme olarak kabul edilmektedir (Erdem, 2018, s. 47). Evlendirme Yönetmeliği ise evlenmeyi, bir kadın ve erkeğin usulüne göre yetki verilmiş bir memur önünde, bir aile kurmak amacı ile yaptıkları medenî hukuk sözleşmesi olarak tanımlamıştır (İkizler, 2018, s. 19). Taraflar evlendikleri anda bu sözleşmenin hayatları boyunca devam edeceğine inanırlar. Hukukî niteliği itibariyle sözleşme olarak kabul edilen evlenme ile taraflar bazı haklara sahip oldukları gibi, belli yükümlülükler altına da girerler (Oğuzman, Dural, 1998, s.2; Schwarz, 1946, s. 2; Gençcan, 2011, s. 252). Bununla birlikte, evlenme sözleşmesi tam bir borçlar hukuku sözleşmesi olarak da düşünülmemelidir ${ }^{1}$ (Öztan, 2015; Feyzioğlu, 1986; Velidedeoğlu, 1965).

Evlenme sözleşmesi, şarta veya vadeye bağlanamadığı gibi taraflar sözleşmenin içeriğini de istedikleri gibi değiştiremezler. Ancak farklı iki bireyin ortak bir hayat kurması pek çok sorunu da beraberinde getirebilmektedir. Bu bağlamda, kendine özgü (sui generis) bir medenî hukuk sözleşmesi olarak kabul edilen evlenme sözleşmesini taraflar, istedikleri anda sona erdiremezler. Ancak, bazı özel durumların oluşması evlilik birliğini sona erdirebilir. TMK çerçevesinde boşanma, hukuken kurulmuş bir evlilik birliğine kanunda öngörülmüş olan sebepler çerçevesinde, taraflar hayattayken hakimin vereceği karar ile son verilmesidir (Gençcan, 2017, s. 97-105).

1 Doktrindeki hakim görüş evlenmenin bir sözleşme niteliğinde olduğu yönündedir. 
Doktrinde, evlilik birliğine son verilmesine ilişkin "Bireyci görüş" ve "Toplumcu görüş" olmak üzere iki temel görüş bulunmaktadır. Bireyci görüs, eşlerin özgür iradeleriyle oluşturdukları evlilik birliğini, yine kendi istekleri çerçevesinde sona erdirebileceklerini savunmaktadır. Bu görüş çerçevesinde serbest boşanma sistemi kabul edilmektedir. Yani, karşılıklı anlaşma ile veya eşlerden birinin tek taraflı irade açıklaması ile evlilik bağı sona erdirilebilmektedir. Toplumcu görüş ise, evlilik birliğinin kolay bir şekilde sona erdirilmesinin ileride toplumsal bir tehlike yaratabileceğini savunur. Boşanmayı kabul etmeyen veya çok katı şartlara bağlayan bu görüş daha çok Katolik Kilise Hukuku'nun felsefesi çerçevesinde oluşturulmuştur (Gençcan, 2017, s. 99).

Dünyada birçok ülkede ise, belirli sebeplere dayanarak, hakim kararıyla boşanma sistemi uygulanmaktadır (Scherpe, 2016, s. 67). $\mathrm{Bu}$ sistemde, kanunda belirlenen boşanma sebeplerinden birine dayanılarak, evlilik birliğini sona erdirmek mümkün kılınmıştır. Buna göre, geçerli bir evlilik varsa, kanunda düzenlenen boşanma sebeplerinden biri veya bir kaçı gerçekleşmişse, hakim kararı ile evlilik birliği sona erdirilebilir (Özdemir, 2003, s. 3). Halen Türkiye'de ve birçok Avrupa ülkesinde uygulamada olan bu sistem teknolojik gelişmelerin hukuk alanında uygulamasının artması ile farklı bir boyuta doğru gitmektedir² (Dutta, 2017, s. 31-56).

\section{B. Boşanmaya İlişkin Farklı Ülkelerdeki Hukukî Uygulamalar}

Birçok ülkede halen, boşanmaya ilişkin klasik hukuk kuralları geçerli olmakla birlikte, teknolojinin gelişmesi ve buna paralel olarak, hukuk kurallarının ve uygulamaların farklılaşmasının bir sonucu olarak, boşanma için uygulanacak kurallarda ve usullerde de değişiklikler yapılmaya başlanmıştır. Klasik hukuk kurallarının uygulamasının değişmesi, yeni hukukî düzenlemeleri de beraberinde getirmektedir. Bununla birlikte, Avrupa'da boşanmaya ilişkin düzenlemeler özellikle son 50 yılda büyük bir gelişim ve değişim göstermiştir.

2 Almanya'da son zamanlarda, mahkeme kararı olmaksızın boşanmanın mümkün olması üzerine çalışmalar yapılmaktadır. 
Avrupa ülkeleri arasındaki politik farklılıklar, boşanma kurallarını da etkilemiştir. Geleneksel aile değerlerini değiştirmek veya bunlara sadık kalmak ve uygulamaya devam etmek konusunda Avrupa'da görüş ayrılıkları ve tartışmalar devam etmekle birlikte 1970'li yıllardan itibaren başta İtalya, Fransa, Almanya, Birleşik Krallık olmak üzere bir çok ülkede reformlar yapılmıştır. Bununla birlikte, İrlanda, İtalya, Malta gibi bazı Avrupa ülkeleri boşanmaya yasal engeller koymuşlar ve bu ülkelerde eşlerin yasal olarak evlilik birliğine son vermesi çok geç kabul edilmiştir.

Birleşik Krallık’ta, 1969 yılında yapılan reformla, tarafların kusuru çerçevesinde boşanmaya hükmedilebileceği kabul edilmekle birlikte, prosedür o kadar kolaylaştırılmıştır ki, yeni düzenleme boşanmanın sürücü ehliyeti almaktan daha kolay olduğu yönünde bir çok eleştiri almıştır. Ama buna rağmen, sadece tarafların karşılıklı rızası ile evlenmeye son verilemeyeceği görüşü hakim olmuştur. Bu gelişmelerden hemen sonra, 1973’te, iki yıl ayrı yaşamak şartıyla tarafların karşılıklı rızası ile boşanma mümkün kılınmıştır (Scherpe, 2016, s. 43). Ve daha sonra, 1977'de özel bir usul yürürlüğe konarak, tarafların rızası ile duruşma yapılmaksızın boşanmanın olabileceği kabul edilmiştir (Thompson, 2011, s. 138-150).

Fransa'da, Fransız Medenî Kanunu ile sadece taraflardan birinin kusuruna dayanılarak boşanma davasının açılabileceği hükme bağlanmıştı. 1975 yılında hukukçu Jean Carbonnier hem kusura dayalı hem de tarafların isteği ile boşanmanın mümkün olabileceğine ilişkin karma bir görüş ileri sürdü (divorce a la carte) (Carbonnier, 2002, s. 541). Boşanma hukukuna ilişkin yapılan bu yeni düzenleme Fransız toplumunun karakterine uygun görüldü ve uygulamaya girdi. Bununla birlikte, boşanma usulünün uzun sürmesi, maliyetlerin yüksek olması ve karmaşık yapısı nedeniyle, 1997 yılında boşamaya ilişkin yeni bir arayış içine girildi. 2004 yılında, yapılan değişikliklerle boşanma nedenleri genişletildi. Fransız Medenî Kanunu'nun 229. maddesinde, tarafların isteği ile boşanmanın mümkün olabileceği kabul edildi. 230. ve 232. maddeler ile, tarafların isteği ile boşanmanın usulü basitleştirildi ve bu durumlarda uygulanacak işlemler azaltıldı. Bu maddeler çerçevesinde, tek bir duruşma ile boşanmaya hükmedilmesi mümkün kılındı. İtalya'da ise, durum diğer 
Avrupa ülkelerine göre biraz daha farklıydı. Boşanma yandaşları ile boşanma karşıtları arasındaki tartışmalar nedeniyle, boşanmaya ilişkin ilk kanun ancak 1970 yılında çıkarıldı. Fakat boşanma davası sadece taraflardan birinin kusuruna dayandırılarak açılabilmekteydi. 1987'de boşanma konusunda yapılan yeni düzenlemelerle, üç yıl ayrı yaşamak koşuluyla her iki eşin boşanmaya ilişkin başvurusu ile evliliğin bitirilebileceği kabul edildi. Bu örneklerin yanında, bazı Avrupa ülkelerinde ise boşanma kanunen yasaklanmıştı. İrlanda, Katolik kimliğinin bir sonucu olarak, 1937 yılında boşanmaya ilişkin anayasal bir yasak getirmişti. Uzun yıllar kanunen boşanmanın mümkün olmadığı İrlanda'da, 1996 yılında yapılan referandumla İrlanda Boşanma Kanunu yürürlüğe girdi ve boşanma yasal olarak kabul edildi. Avrupa Birliği üyesi olan Malta ise, yasal olarak boşanmayı en son kabul eden Avrupa ülkesidir. 2011 yllında yapılan referandum ile Malta Boşanma Kanunu kabul edildi. Ancak bununla birlikte, Malta Medenî Kanunu (m. 66B) eşlerin boşanma kararından önceki son dört yılda ayrı yaşamalarının zorunlu olması gibi bazı ağır hükümler de koydu (Scherpe, 2016, s. 53-60).

Boşanma konusunda doktrinde çok farklı görüşler olmakla birlikte, ${ }^{3}$ Türkiye'de TMK çerçevesinde, m. 161 ve 166 arasında, boşanma nedenleri sayıca sınırlı olarak belirlenmiştir (Kırmızı, 2018, s. 644). TMK'da kabul edilen boşanma sebepleri, mahiyetleri ve kapsamları bakımından birbirlerinden farklıdır. Buna göre, zina, hayata kast, pek kötü muamele, onur kırıcı davranış, küçük düşürücü suç işleme, haysiyetsiz hayat sürme, terk ya da akıl hastalı̆̆ı

3 Doktrinde kabul edilen boşanmaya ilişkin görüşler üç temel başlık altında toplanabilir. Boşanmaya yer vermeyen görüş, X. yüzyıldan itibaren Kanonik hukuk tarafından benimsenmiştir. Katolik ülkelerde ağırlıklı olarak uygulanmış olan bu görüşe göre, evlilik bağının tamamen ve kesin surette ortadan kaldırılması söz konusu değildir. Örneğin, İtalya'da uzun yıllar boşanma kabul edilmemiş, ancak 1974 yılından itibaren boşanma hukuken uygulamaya girmiştir. Boşanmanın serbest olması görüşü, eşlerin beraber kurdukları evlilik birliğini, yine istekleri doğrultusunda kaldırabilmesine dayanmaktadır. Roma hukukunda, Babil, İbrânî hukuklarında uygulanmıştır. Boşanmanın bir sebebe dayanılarak hakim hükmüyle gerçekleşmesi görüşü ise, yukarıda bahsedilen iki görüşten de etkilenmiştir. Belli sebeplerin mümkün olması halinde boşanma, ancak hakim tarafından hükme bağlanabilmektedir. Almanya, Fransa, İsviçre'de uygulanmaktadır. TMK'da da boşanmanın ancak hakim hükmüyle mümkün olabileceği kabul edilmiştir (Akıntürk, 2006, s. 245 -255). 
gibi sebepler özel boşanma nedenlerinden kabul edilmiştir (Gençcan, 2017, s.120-130; Erdem, 2018, s. 100; Özuğur, 2013, s. 93).

Evlilik birliğinin temelinden sarsılması, eylemli ayrılık veya eşlerin artık ortak hayata devam etmek istememesi gibi durumlarda, boşanmanın genel sebeplerinden söz edilmektedir (Öztürk, 2015, s. 23- 25). Bunların genel sebep olarak adlandırılmasının nedeni ise, bu sebeplerin tek tek belirlenmesinin mümkün olmamasıdır. TMK m. 166 çerçevesinde, eşlerin, ortak hayatı sürdürmeleri kendilerinden beklenmeyecek derecede evlilik birliği temelinden sarsılırsa, eşlerden her biri boşanma davası açabilir.

Zina, hayata kast, pek kötü muamele, onur kırıcı davranış, küçük düşürücü suç işleme, haysiyetsiz hayat sürme, terk ya da akıl hastalığı sebeplerinden birine dayanılarak boşanma davası açılamıyorsa, ancak tarafların evlilik birliğini devam ettirmeleri kendilerinden beklenemeyecek durumda ise genel sebeplere dayanılarak dava açlabilecektir (Öztan, 2013, s. 473- 475).

\section{II. “Dijital Boşanma"nın Tanımı ve Unsurları}

\section{A. "Dijital Boşanma" Kavramı}

Dijital boşanmayı tanımlamadan önce, dijital teriminin ne anlama geldiğini araştırmak gerekir. Aslında, Latince'den diğer dillere geçen digital kelimesine tarih boyunca sayısal, sayılara ilişkin, parmak gibi farklı anlamlar yüklenmiştir. ${ }^{4}$ Bugün özellikle, bilgisayar ortamında girilen tüm verilerin 0 ve 1 ile kodlanmasının bir sonucu olsa gerek, "dijital" terimi, sıklıkla bilgisayar ortamını ifade etmek için kullanılmaktadır. Türkçe’ye de diğer dillerdeki kullanımına benzer şekilde "dijital" olarak giren bu terim, verilerin bir ekran üzerinde elektronik olarak gösterilmesi anlamına da gelmektedir.

"Dijital Boşanma" (digital divorce) olarak Google arama motorunda, herhangi bir arama yapıldığında iki farklı kavram ile karşlaşllmaktadır. Bunlardan ilki, boşanma sürecinde eşlerin çeşitli dijital

4 Digital teriminin sözlük karşılığı (2018). https://en.oxforddictionaries.com/ definition/digital, son erişim: 15.06.2018 
platformlar veya bloglar içinde yaptıkları faaliyetleri, yazışmaları, sosyal medya kullanımlarını içine almaktadır.

Eşlerin, bu platformlarda yaptıkları paylaşımların evlilik sürecine etkisi ve boşanma durumunda delil nitelikleri tartışma konusu yapılmakta, yani usulî bir değişiklikten ziyade, dijital medyanın gelişmesiyle birlikte, eşler arasındaki özel hayat, sadakat gibi kavramlar tartışmaya açılmaktadır (Güneş Peschke, 2013, s. 857-883). $\mathrm{Bu}$ tür paylaşımların veya yazışmaların evlilik birliğini ne şekilde etkilediği veya zedelediği gibi konular esas itibariyle ele alınmaktadir (Landers, 2013; Grosdidier, 2017).

Hukuk artık dijital ortamların gelişmesiyle birlikte farklı bir boyuta geçmiştir. Bu çerçevede, artık birçok hukukî işlemin online olarak yapılması gündeme gelmiş ve hatta uygulamaya girmiştir.

Dijital boşanma teriminin asıl anlamı, teknolojinin gelişiminin, boşanma usulüne etkisi çerçevesinde karşımıza çıkmaktadır. Klasik boşanma usulleri, zamanla yerini farklı düzenlemelere bırakmış ve yeni boşanma usulleri uygulamaya girmiştir. Örneğin, Dutta'ya göre (2017, s. 47), yeni teknolojik gelişmeler tarafları hızlı ve basit boşanma usullerine götürmektedir. Evliliğin sona erdirilmesine ilişkin sürecin uzaması evliliği kurtarmak yerine, tarafların daha fazla üzülmesine ve yıpranmasina neden olmaktadır. $\mathrm{Bu}$ nedenle, eşler açısından da en kısa ve hızlı şekilde boşanmaya karar verilmesi, onların gelecekteki yaşamlarına yön vermeleri açısından önemlidir. Bu nedenle, son gelişmeler aslında devletleri de yeni usulleri, kendi hukuklarına almaları gerektiği konusunda zorlamaktadir.

Ayrıca, son yıllarda birçok Avrupa ülkesinde, adli yargılamanın yanında, ihtiyarî uyuşmazlık çözüm yollarından arabuluculuk müessesesi uygulanmaktadır. Arabuluculuğun özel bir uygulama şekli olan aile arabuluculuğu ile aslında mahkemelerde çözümlenmesi gereken birçok uyuşmazlık kısa ve ucuz bir maliyetle çözüme kavuşturulmaktadır. Bir çok Avrupa ülkesinde uygulanmakta olan aile arabuluculuğu henüz Türkiye'de kabul edilmemekle birlikte, bu konuya ilişkin altyapı çalışmaları devam etmektedir (Parkinson, 2014, s. 347). 
Teknolojinin gelişimiyle birlikte, bugün artık, boşanma usullerinde de farklı uygulamalar ortaya çıkmaya başlamış ve bununla birlikte, hukuk usulü de mecburen bu değişime ayak uydurmak zorunda kalmıştır. Dijital boşanma da bu bağlamda, boşanma prosedürünü online ortama taşımış ve tarafların biraraya gelmesi sonucunda oluşabilecek olumsuzlukları en aza indirmek amacıyla uygulamaya girmiştir.

Dijital boşanma, aslında verilerin dijital bir ortama girilmesiyle başlayan usulî bir süreci karşımıza çıkarmaktadır. Yani tarafların boşanmasına ilişkin tüm belgeler, formlar, anlaşma metinleri, elektronik aygitlar ya da bilgisayarlar aracılığıyla, belli kayıt ortamlarına internet yoluyla kaydedilmektedir.

\section{B. "Dijital Boşanma”nın Uygulaması}

Günümüzde, teknolojinin hukuku etkisi altına alması ile hukuk mecburen teknolojiyi izlemek zorunda kalmıştır. Bulunduğumuz bu çağda, "online dating”le, yani online arkadaşlıkla başlayan süreç, evlilikle devam ederek dijital boşanma ile sona erebilmektedir. Böylece, hukukta yeni bir boyuta geçilmiştir. Hayatın içindeki bazı hukukî uygulamalar teknolojinin etkisiyle, daha basite indirgenmeye başlanmıştır. Böylece, çok hızlı bir şekilde sonuca ulaşılmaya çalışılmaktadır. Bunun sonucunda, yeni bir kavram ortaya çıkmıştır: Legaltech (Teknohukuk ${ }^{5}$ ).

Legaltech ile hukuk hizmetlerine teknoloji dahil olmuş ve hatta bazı yazılımlar hukukî işlemlerde doğrudan doğruya kullanılmaya başlanmıştır. Henüz Türkiye'de kabul edilmemekle birlikte, bunların en çarpıcılarından bir tanesi olan, online boşanma veya orijinal adıyla "digital divorce" (dijital boşanma), Birleşik Krallık ve Hollanda'da uygulamaya girmiştir. Almanya'da ise, ${ }^{6}$ mahkemeye

5 Legaltech terimi, İngilizce ve Almanca'da hukuk ve teknolojiyi birleştiren bir kelime olarak kullanılmaya başlanmış, son zamanlarda uygulamaya girmiş bir terimdir. Yaptığım araştırmalarda, "legaltech"in herhangi bir Türkçe çevirisine rastlamadım. Bu nedenle, "legaltech" terimi için Türkçe "teknohukuk" teriminin kullanılmasının uygun olduğunu düşünüyorum.

6 Geçtiğimiz son on beş yılda Almanya'da boşanma oranlarında büyük artış olmuştur. En yüksek artış ise, 213.975 boşanma sayısı ile 2003 yılında görülmüş, daha sonra 2014 yılında bu sayı 166.000'ne düşmüştür (Scherpe, 2016, s. 69). 
başvurmaksızın, online ortamda boşanma kararı alınmasına ilişkin yeni görüşler ileri sürülmüş ve halen tartışılmaktadır (Dutta, 2017, s. 47-55).

Son yıllarda, hukukî uyuşmazlıkların mahkemelerde kısa sürede sonuçlandırılabilmesi amacıyla, Büyük Britanya Devleti tarafindan bazı işlemlerin online olarak yapılmasına olanak veren yazılımlar geliştirilmiştir. Politikacıların da desteği ile, bu tür işlemlerin ülke çapında uygulamasının mümkün hale gelmesi amaçlanmıştır (Welstead, 2012, s. 21-25).

Büyük Britanya'da, mahkemelerin online sistemlerini genişletmeleri amacıyla yapılan bir milyar poundluk yatırımın sonucunda, Ocak 2018'de, boşanmak isteyen taraflarca doğrudan mahkemelerin sistemlerine kayıt yapılarak, gerekli evraklar online olarak yüklenmek suretiyle boşanma başvurusunda bulunulabilmektedir. Ayrıca bu hukukî işlemlerde, harç ödemeleri de online şekilde yapılmaktadır. Özellikle boşanmak isteyen eşlerin bir araya gelmeden, kavgasız bir şekilde ayrılmalarını amaçlayan dijital boşanmaya ilişkin Nottingham'da, Doğu Midlands Boşanma Merkezi’nde 10 aylık pilot bir uygulamaya başlanmıştır. Ülkedeki politikacılar ve bakanlar tarafından desteklenen bu uygulamanın genişleyerek tüm ülkeye yayılması planlanmaktadır. Bu amaçla, bu uygulamayı hayata geçirmek için azımsanmayacak bir bütçe de ayrılmış ve kullanılmaya başlanmıştır (Yorke, 2017).

Dijital boşanma, aslında boşanma taleplerinin online olarak dijital bir platforma gönderilmesi ile başlayan boşanma sürecinin sonunda, mahkeme kararıla evlilik birliğine son verilmesidir. Ancak burada dikkat çeken nokta, tarafların bir araya gelmeksizin boşanma kararına hükmedilmesidir. ${ }^{7}$ Tarafların bir araya gelmeksizin boşanması ne şekilde mümkün olabilir ve hangi usulî işlemler uygulanmakta diye sorguladığımızda, aslında hukuk usulünde temel değişikliklere gidilmeksizin, teknolojiden yardım alındığı görülmektedir.

7 Mahkeme tarafindan yapılan basın bildirisi (2018), https://www.gov.uk/government/news/hm-courts-and-tribunals-service-tests-fully-digital-divorceapplication, son erişim: 15.10.2018. 
Common law sisteminin uygulandığı Birleşik Krallık hukuk sistemi, Roma hukukuna dayanan Kita Avrupası Hukuk Sistemi'nden oldukça farklıdır. Bu nedenle, Birleşik Krallık'ta, hukuk yargılamasında diğer Avrupa ülkelerine göre farklı uygulamalar bulunmaktadır. Anlaşmalı boşanmayı uzun yıllar kabul etmeyen Birleşik Krallık'ta, 1996 yılında kabul edilen Aile Hukuku Kanunu ile boşanma mevcut durumdan daha karmaşık bir hale gelmiştir. Boşanma süresinin uzaması ve buna ilişkin şikayetlerin artmasıyla, 2001 yılında 1973 yılındaki uygulamaya geri dönülmüş ve boşanmaya ilişkin usul işlemleri basitleştirilmiştir (Scherpe, 2016, s. 50).

Birleşik Krallık'ta belirlenen pilot bölgelerde, Ocak 2018'in ilk haftasında online boşanmaya ilişkin 130 kayıt alınmıştır. Başvurular kolay ve kısa sürede, evrakların postada kaybolma kaygısı yaşanmadan yapıldıkları için uygulamanın tüm ülkeye yayılması planlanmaktadır. Büyük Britanya'da yargı reformu çerçevesinde yapılan bu gelişmelerle, çevreci bir yaklaşımla kağıt israfının da önüne geçilmektedir. Büyük Britanya'da geliştirilen yeni hukukî yazılımlarla, sadece boşanmada değil, farklı hukukî işlemlerde de online hizmetlerin artırılarak uygulamaya konulması amaçlanmaktadır.

Hollanda'da da durum Birleşik Krallık'tan çok farklı değildir. Bir boşanma davası için yapılan masraflar, mahkeme harçlarıyla birlikte 3000 Euro'ya yakın tutarken, internet üzerinden boşanma başvurularına olanak verilmesiyle birlikte, bu masraflar neredeyse onda bire kadar inmiştir. Ayrıca, boşanma kararlarının verilmesi için gereken süreler de aynı şekilde, dijital boşanma usulüyle birlikte kısalmıştır.

\section{Dijital Boşanmada Usul}

Aslında, boşanma dönemi, boşanmak isteyen her iki eş için de gerek finansal gerekse duygusal açıdan yıpratıcı bir süreçtir. Dijital boşanma uygulaması bir çok ülkede kabul edilmiş olan ve Türkiye'de de sıklıkla uygulanmakta olan anlaşmalı boşanmaya benzemekle birlikte, bazı farklılıkları da içinde barındırmaktadır. Avrupa ülkelerinin bir çoğunu etkisi altına alacağ 
dijital boşanmada taraflar, bir araya gelmeden kısa ve ucuz bir maliyetle çözüme ulaşabilmektedirler.

Bir tuşla boşanmanın mümkün olması acaba tarafların yararına mıdır yoksa çok kısa sürede boşanmak eşlerin menfaatlerini zedeler mi? Bu yeni usulü uygulamaya koymadan önce, ekonomik ve hukukî sonuçlarının yanında, sosyolojik boyutlarının da detaylıca tartışılması gereklidir.

Dijital boşanmada, klasik boşanmaya göre, farklı usulî işlemlerin yapılması gerekmektedir . ${ }^{8}$ Dijital boşanmaya karar veren tarafların, internet üzerinden bu usule ilişkin başvuru formlarını düzgün bir şekilde doldurmaları ve sisteme yüklemeleri ile prosedür başlar. Çiftin mal varlıklarının bulunması ve çocuklarının olup olmamasına göre de yapılacak işlemler arasında farklılıklar bulunmaktadır. $\mathrm{Bu}$ bağlamda, boşanmayı isteyen çiftin çocuklarının olmaması, anlaşmayı daha kolay şekillendirebilecek ve daha kısa bir zamanda tarafları sonuca götürebilecektir.

Boşanmak isteyen eşlerin çocuklarının bulunması halinde ise, boşanma sonrasında çocukların velayetini kimin alacağı konusunda anlaşmaya varılmış olmalıdır. Velayet, ana ve babaya, çocuğun şahsı ve malları üzerinde hem bazı haklar tanır hem de onlara bazı yükümlülükler yükler (Akıntürk, 2006; Dural, Öğüz ve Gümüş, 2005; Oğuzman ve Dural, 1998). Bu nedenle, çocuğun velayeti hakkında eşlerin ortak bir karara ulaşması, boşanmanın gerçekleşebilmesi için önemli bir şarttır. Bu nedenle, boşanacak eşler öncelikle kendi aralarında, çocukların velayetine ilişkin ebeveyn anlaşması yapmalidirlar.

Eşler boşanma halinde, çocuk üzerinde ortak velayeti koruyabilecekleri gibi taraflardan sadece birine, anaya veya babaya velayet hakkını bırakabilmektedirler. Bu durumda çocuk üzerinde velayet hakkı olan ana veya baba velayet hakkını hukuken kullanabilecektir.

Avrupa'da çok sıklıkla uygulamada olan ortak velayette ana ve baba boşansa dahi çocuk üzerindeki velayet haklarını yine evliymiş gibi birlikte kullanırlar. Yani, ana ve babaya tanınan velayet -............

84722 sayılı Kanunun 9. Maddesine göre, evliliğin sona ermesi 4721 sayılı Türk Medenî Kanunu hükümlerine tabidir (Ural ve Karagülmez, 2003) 
hakkının niteliğinde genellikle bir değişiklik olmaz. Bu nedenle, çoğunlukla boşanmalarda ortak velayet muhafaza edilmekte, böylece çocuklarla ana babanın arasındaki bağ da zedelenmeden korunmaktadır (Vazetti, 2016, s. 1-7). Bu şekilde, ana ve baba evliyken olduğu gibi velayet hakkını da eşit olarak kullanmaya devam ederler . ${ }^{9}$

Bunun yanında, eşler mal varlıklarına ilişkin, finansal ve ekonomik konularda da anlaşmaya varmış olmalıdırlar. Her ülkenin kendi hukuk kuralları içinde farklı mal rejimleri uygulanmaktadır (Öztan, 2015, s. 326- 328). ${ }^{10}$ En temel olarak bu iki konuda anlaşmaya varılamamışsa dijital boşanma gerçekleşmeyecektir. Bu tür boşanmalara dijital boşanma denmesinin sebebi, tarafların bu anlaşmaları yapmaları ve sisteme online olarak yüklemelerinden kaynaklanmaktadır. Mahkeme sistemine bu anlaşmalar girildikten sonra, ayrı bir duruşma yapılmaksızın boşanmaya hükmedilebilir. $\mathrm{O}$ halde dijital boşanmanın uygulanabilmesi için tarafların öncelikle, boşanma ve diğer temel konularda anlaşmış olmaları gerekir. Bu haliyle, aslında dijital boşanma Türk Medenî Kanunu (TMK.), İsviçre Medenî Kanunu (ZGB), Alman Medenî Kanunu (BGB), Avusturya Medenî Kanunu (ABGB)'de yer alan anlaşmalı boşanmaya çok benzemektedir. Hatta, Avusturya'da, tarafların anlaşmalı boşanmada, duruşma sırasında hazır olmalarına gerek olmadığı yönünde doktrinde tartışmalar bulunmaktadır (Rechberger ve Simotta, 2010, s. 544). O halde, Avusturya'da anlaşmalı boşanmaya ilişkin uygulamalar, İsviçre ve Alman hukukuna göre biraz daha genişletilmeye çalışılmaktadır. Bunun yanı sıra, İsviçre'de anlaşmalı boşanma hallerinde, teknolojik

9 Ortak velayet henüz Türkiye'de kanunlaşmamış olmakla birlikte, Türkiye'nin 14 Mart 1985 tarihinde imzaladığı "11 No'lu Protokol ile Değişik İnsan Haklarını ve Ana Hürriyetleri Korumaya Dair Sözleşme’ye Ek 7 No’lu Protokol” onaylanarak, 25 Mart 2016 tarihli 6684 sayılı kanunla uygun bulunmuştur. Bu kapsamda, Ek 7 No'lu Protokol'ün 5. Maddesi "Eşler evliliğin sona ermesi durumunda, çocukları ile ilişkilerinde medenî haklar ve sorumluluklardan eşit şekilde yararlanırlar" hükmü gereğince, Yargitay 2. Dairesi çocuğun güvenliğine ve üstün yararına binaen, velayetin ana ve babaya ortak verilmesinin artık mümkün olduğu görüşünü benimsemektedir.

10 TMK m. 202 çerçevesinde, eşler arasında edinilmiş mallara katılma rejiminin uygulanması asıldır. Ancak bununla birlikte, eşler, yasal mal rejiminin dışında kalan mal ayrılığı rejimi, paylaşmalı mal ayrılığı rejimi, mal ortaklığı rejimlerinden birisini seçerek de bu rejimlere göre belirlenen düzenlemelere tabi olabilirler (Demirel İçöz ve Büberci, 2017, s. 218). 
gelişmeler çerçevesinde, taraf duruşmaya gelemese dahi, anlık görüntü ve ses nakli yoluyla duruşmaya katılabileceği tartışılmaktadır (Hausheer ve Walter, 2012, s. 2651).

Ancak, dijital boşanmada sadece anlaşma da yeterli olmamaktadır. Tarafların boşanmayı istediklerine ilişkin belgeleri, üzerinde anlaştıkları velayete ve finansal anlaşmaya ilişkin formları da mahkemenin sistemine yüklemeleri gerekmektedir. Bu işlemleri yaparken taraflar bir avukattan yardım alabilecekleri gibi doğrudan kendileri de başvuruda bulunabilmektedirler. Tabi, bir avukattan yardım alınması, işlemlerin daha sağlıklı olarak yürütülmesi açısından önem arz etmekle birlikte, boşanma maliyetini arttıracağına da şüphe yoktur. Ancak, tarafların göremediği eksiklikleri avukatın fark etmesi ve tarafları uyarması uygulamanın daha sağlıklı yürümesi açısından önem taşımaktadır. Bu arada, anlaşmalı boşanma dahi olsa, Almanya'da avukata başvurmaksızın boşanma davası açılamamaktadır.

\section{D. "Dijital Boşanma" ile Anlaşmalı Boşanma Arasındaki Benzerlikler}

İsviçre hukukunda, boşanmanın, kişilik haklarına ilişkin bir yargılama faaliyeti olması nedeniyle, boşanma yargılamasında sınırlı re'sen araştırma ilkesi geçerlidir. Boşanma yargılaması boyunca yapılacak tüm mahkeme işlemlerinde tarafların bizzat hazır bulunmaları gerekmektedir (Akkaya, 2017, s. 194). Tarafların duruşmaya katılmaksızın sadece vekille temsil edilmeleri mümkün değildir. Anlaşmalı boşanmada da, tarafların bizzat hazır bulunması gerekmektedir. Türk hukukunda olduğu gibi, hakimin tarafların boşanmaya ilişkin iradelerini anlayabilmesi için tarafları dinlemesi gerekmektedir. Bu çerçevede, hakimin boşanma kararı verebilmesi için tarafların boşanma konusunda iradelerini serbestçe beyan ettikleri konusunda kanaate sahip olması önemlidir (Oberhammer, Domej ve Haas, 2014). Ancak bu kuralın da istisnaları bulunmaktadır. Örneğin, İsviçre'de hazır olmaktan muaf tutulan tarafın bulunduğu yerdeki mahkeme istinabe edilerek dinlenebilir (Ercan, 2000, s. 77). Birleşik Krallık’ta anlaşmalı boşanma hallerinde, özel usule gidilmesi durumunda duruşma yapılmaksızın, boşanma kararının 
verilebileceği kabul edilmiştir ve uzun yıllardır uygulanmaktadır. Portekiz'de ise, boşanma ve bunun sonuçları konusunda anlaşan tarafların idarî bir işlemle, Nüfus Kayıt Merkezi'ne başvurarak boşanması mümkün kılınmıştır (Scherpe, 2016, s. 65).

4721 sayılı Türk Medenî Kanunu'nda, irade ilkesi kabul edilmemiştir. Yani, Türk Medenî Kanunu çerçevesinde eşlerin anlaşarak boşanması mümkün olmakla birlikte, eşlerin hakim kararı olmaksızın mahkeme dışında evlilik birliğine son vermeleri olanaksıdır (Gençcan, 2016, s. 347-351). TMK 166/3’te yer alan, tarafların evlilik birliğini sona erdirmeye yönelik olarak hazırladıkları ön anlaşmalar ile mahkemeye yaptıkları başvurular, anlaşmalı boşanma adı altında Türk hukukunda sıklıkla uygulanmaktadır (Ertuğrul ve Ertuğrul, 2011; Özuğur, 2013). Aslında, bu şekliyle dijital boşanma, TMK m. 166/3'te bulunan anlaşmalı boşanmaya benzemektedir. Dijital boşanmada, taraflar, çocukların velayetine ilişkin ve kendilerinin ekonomik-malî haklarına ilişkin anlaşmaları yaparken sonuçları konusunda, anlaşmış ve mutabakata varmış olmalıdırlar (Öztan, 2015, s. 598; Gençcan, 2017, s. 739; Yarg. 2. HD. 23.02.2002, 12857-14507) . Öncelikle yukarıda bahsedilen velayet ve mal varlığının paylaşımı konularında anlaşma yapılmadan dijital boşanmanın uygulanması mümkün olmamaktadır.

Birçok Avrupa ülkesinde, boşanma usulünde eşlerin duruşmalara katılma zorunluluğu olmakla birlikte, bunun istisnaları da bulunmaktadır. Örneğin, Avusturya hukukunda tarafların boşanma sırasında hazır bulunmasının gerekliliğine rağmen, istisnai olarak tarafın duruşmada hazır bulunması zorunlu değilse, hakimin tarafı duruşmaya davet etmesi halinde duruşmaya katılım zorunlu hale gelir (Rechberger ve Simotta, 2010, s. 544). Bunun yanı sıra, Avusturya Medenî Kanunu (ABGB) çerçevesinde anlaşmalı boşanmada tarafların duruşmada hazır bulunması zorunlu olmamakla birlikte, doktrinde bu konuda iki görüş hakimdir. Buna göre, taraflar duruşmaya gelmeseler dahi vekilleri sufatıyla temsil edilebilirler. Diğer bir görüşe göre ise, tarafların menfaati açısından duruşmada her iki tarafın da hazır bulunması gerekir. Bu görüş aslında İsviçre ve Alman hukukunda halen uygulanmaktadır (Akkaya, 2017, s.199). 
Dijital boşanma henüz İsviçre'de uygulanmamakla birlikte, anlaşmalı boşanmalarda teknolojik gelişmelerden yardım alınmasının mümkün olabileceği düşünülmeye başlanmıştır. İsviçre Medenî Kanunu'na (ZGB) göre, hakimin boşanma kararı verebilmesi için tarafları dinlemesi gerekmektedir. Ancak taraflar mazeretleri nedeniyle, mahkemeye gelemeyecek durumdalarsa, bu halde taraflarin video konferans yoluyla dinlenebileceği görüşü doktrinde savunulmaktadır (Hausheer ve Walter, 2012, s. 2651).

TMK m. 166/3 çerçevesinde, eşlerin birlikte mahkemeye başvurması ya da bir eşin diğerinin açtığı davayı kabul etmesi halinde anlaşmalı boşanma söz konusu olmaktadır (Akıntürk, 2006, s. 252160). Bu madde hükmüne göre, evlilik en az bir yıl sürmüş ise eşlerin birlikte mahkemeye başvurması ya da bir eşin diğerinin davasını kabul etmesi halinde, evlilik birliği temelinden sarsılmış sayılır. Eşlerin bir yıllık süreyi birlikte geçirmiş olmaları şart değildir. Yani, bu bir yıllık süre içinde eşlerin ortak bir hayat sürmeleri önemli değildir (Gençcan, 2017, s. 719-724; Oğuzman ve Dural,1998, s. 128). ${ }^{11} \mathrm{Bu}$ halde boşanma kararı verilebilmesi için, hakimin tarafları bizzat dinleyerek iradelerinin serbestçe açıklandığına kanaat getirmesi ve boşanmanın malî sonuçları ile çocukların durumu hususunda taraflarca kabul edilecek düzenlemeyi uygun bulması şarttır (Yıldırım, 2014; Gençcan, 2017, s. 717).

Kanuna göre, bu durumda evlilik birliği temelinden sarsılmış kabul edildiği için hakim ayrıca bu durumu re'sen araştırmaz. Ancak hakimin boşanmaya karar vermeden önce, tarafları bizzat dinleyerek, iradelerinin serbestçe açıklandığına kanaat getirmesi gerekir (Yarg. 2 HD. 14.04.2003, E. 2003/4255, K. 2003/5305; Yarg. 2. HD. 24.03.2009, E. 2008/3130, K. 2009/5388). Hakimin sadece taraflarin vekillerini dinlemesi ve bunlara istinaden boşanmaya karar vermesi uygun olmaz (Ertuğrul ve Ertuğrul, 2011, s. 1022; Özuğur, 2013, s. 490; Yarg. 2. HD. 28.04.2005, 4351/5460). ${ }^{12}$

11 Buradaki bir yıllık sürenin dolmadığının anlaşılması durumunda, hakimin diğer koşulları incelemeden davanın reddedilmesi gerekmektedir.

12 "Taraflar hazır bulunup, bizzat anlaştıklarını açıklamaz veya hakim, tarafların anlaşmasını uygun görmezse, taraflardan delilleri sorulup, toplanması sonucunda evlilik birliğinin temelinden sarsılıp sarsılmadığının TMK m. 184 çerçevesinde belirlenmesi gerekirken, davacı ve davalının kendileri 
TMK m. 166/3’ün 2. cümlesinde geçen, “...boşanma kararı verilebilmesi için, hakimin tarafları bizzat dinleyerek iradelerinin serbestçe açıklandığına kanaat getirmesi ve boşanmanın malî sonuçları ile çocukların durumu hususunda taraflarca kabul edilecek düzenlemeyi uygun bulması şarttır.” Türk hukuku, boşanmanın malî sonuçları ve mal rejiminin tasfiyesi bakımından, İsviçre ve Alman hukukundan ayrılmaktadır.

Anlaşmalı boşanmada hakimin, tarafların mal varlığına ve varsa çocukların velayetine ilişkin yaptıkları anlaşmaları uygun bulması sonucunda boşanma kararı verilebilir. Ancak hakimin tarafları dinlemesi gerektiğine ilişkin (Yarg. 2. HD. E. 2010/18621 K. 2011/19302) şart conditio sine qua non (zorunlu) olduğu için, tarafların dinlenmesi usul açısından olmazsa olmaz bir şart olarak karşımıza çıkmaktadır. Anlaşmalı boşanma davasında, tarafların bizzat dinlenmesi kamu düzenine ilişkindir (Yarg. 19.02.1990, K. 10658/2000). İsviçre Federal Mahkemesi'nin ve Yargitay'ın yerleşik içtihatları da bu yöndedir (Yarg. 2. HD. 22.02.1990, 10796/2176; Yarg. 2. HD. 07.04.2005, 3734/5662). ${ }^{13}$ Bununla birlikte, anlaşmalı boşanmada, hakimin davete rağmen mazeretsiz olarak duruşmaya gelmeyen tarafı zorla duruşmaya getirme yetkisi bulunmamaktadır. Bu durumda, anlaşmalı boşanmanın şartları oluşmadığı için davanin reddine karar verilmelidir.

Almanya'da 1938 yılında kabul edilen Evlilik Kanunu'nda, boşanmaya ilişkin hükümler de yer almaktaydı. Ancak, Avrupa'da Aile Hukukuna ilişkin değişiklikler, Almanya'yı da etkiledi. 1976 yılında boşanmaya ilişkin yeni düzenlemeler getirildi. Alman Medenî Kanunu'nda (BGB), 1564-1568 maddeleri arasında boşanmaya ilişkin düzenlemeler bulunmaktadır (Detloff, 2015, s. 171-175). Alman hukukuna göre, eşler ancak Aile mahkemesinde evlilik birliğine son verebilir ve boşanabilir.

dinlenmeden, taraf vekillerinin beyanı ile yetinilerek boşanmaya karar verilmesi usul ve kanuna aykırı bulunmuştur."

13 "Davalı dinlenilmeden sadece davacının beyanı ile yetinilerek boşanmaya karar verilmesi usul ve yasaya aykırıdır."(Yarg. 2. HD. 09.04.2015, E. 2015/5646, K. 2015/7190; Yarg. 2. HD. 21.03.2005, K. 2419/4443). 
Alman Aile Hukukuna İlişkin Yargılama Usulü ve Çekişmesiz Yargi İşleri Kanunu, 128/1 çerçevesinde, re'sen araştırma ilkesinin etkin kullanımı açısından, boşanma sırasında tarafların duruşmada hazır bulunmalarını öngörmektedir. Bu şekilde, hakim tarafından taraflar aydınlatılarak, eşlerin ve varsa çocuklarının menfaati korunabileceği gibi arabuluculuğa da yönlendirilebilmektedirler.$^{14}$

O halde, anlaşmalı boşanmada, İsviçre ve Alman hukukunda olduğu gibi TMK çerçevesinde de, hakimin mutlaka boşanma süreci içinde tarafları dinleyip boşanmayı istediklerine ikna olması gerekir. Alman hukukuna göre, tarafların duruşmaya katılarak mahkemede boşanmak istediklerine ilişkin beyanda bulunmaları gerekir. Avusturya hukukunda ise, tarafların duruşmada hazır olmaları zorunluluğunu getiren açık bir hüküm bulunmamaktadır. Keza, Birleşik Krallık'ta anlaşmalı boşanma hallerinde, duruşma yapılmaksızın boşanmaya hükmedilebilmesi, dijital boşanma usulünden önce de uygulanan bir yöntem olarak karşımıza çıkmaktadır.

Türk hukuku açısından, taraflar duruşmaya katıldıktan ve boşanma konusunda taraf iradelerini açıkladıktan sonra, bunlar mahkeme tutanağina geçirilerek HMK m. 154 çerçevesinde taraflara ayrı ayrı imzalattırılır. ${ }^{15}$ Tarafların duruşmaya gelmemelerinin sonuçları, HMK m. 150'de düzenlenmiştir. ${ }^{16}$

Alman hukukunda, eşler boşanmak için birlikte başvuru yapmışsa, hakimin yargilamayı ertelemesi mümkün görülmemektedir. Ancak, her iki eşin de yargılamanın ertelenmesini istemesi halinde,

14 Aile arabuluculuğu aktif olarak birçok Avrupa ülkesinde uygulanmaktadir. Parkinson, L. (2011), 347. Karma bir hukuk sisteminin hakim olduğu Malezya'da da, mahkeme tarafları boşanma sırasında arabuluculuğa yönlendirebilmektedir ( Stark, 2005, s. 93).

15 HMK m. 154: Hakim, tahkikat ve yargılama işlemlerinin icrasıyla, iki tarafın ve diğer ilgililerin sözlü açıklamalarını, gerekirse özet olarak zabıt kâtibi aracılığıyla tutanağa kaydettirir.

16 HMK m. 150: 1. Usulüne uygun şekilde davet edilmiş olan taraflar, duruşmaya gelmedikleri veya gelip de davayı takip etmeyeceklerini bildirdikleri takdirde dosyanın işlemden kaldırılmasına karar verilir. 2. Usulüne uygun şekilde davet edilmiş olan taraflardan biri duruşmaya gelir, diğeri gelmezse gelen tarafın talebi üzerine yargılamaya gelmeyen tarafın yokluğunda devam edilir veya dosya işlemden kaldırılır. 
hakim tarafından en fazla altı aya kadar erteleme kararı verilebilir (Akkaya, 2017, s. 198).

Eşlerin anlaşmalı boşanma doğrultusunda karşılıklı boşanma talebinde bulunmaları halinde bir "çekişmeden" söz edilememektedir. Eşlerin her ikisi de boşanmayı istemekte ve birlikte davacı olmaktadırlar (Gençcan, 2017, s. 722- 725). Anlaşmalı boşanmada, taraflar ekonomik ve malî konulara ilişkin bir ön anlaşma (protokol) imzalarlar (Tekinay, 1990, s. 126-127). Bu protokolde boşanmanın malî sonuçları, çocuk varsa, çocukların velayet durumları ve masraflarının ne şekilde eşler tarafindan karşılanacağı gibi düzenlemeler yer almaktadır. TMK m. 182'ye göre, mahkeme boşanma veya ayrılığa karar verirken, olanak bulundukça ana ve babayı dinledikten ve çocuk vesayet altında ise vasinin ve vesayet makamının düşüncesini aldıktan sonra, ana ve babanın haklarını ve çocuk ile olan kişisel ilişkilerini düzenler. Velayet hakkı kendisine verilmeyen eşin çocuk ile kişisel ilişkisinin düzenlenmesinde, çocuğun özellikle sağlık, eğitim ve ahlâk bakımından yararları esas tutulur. Bu eş, çocuğun bakım ve eğitim giderlerine gücü oranında katılmak zorundadır. Ancak, bu hususlarda sadece tarafların anlaşması yeterli değildir. Bu protokolün, ayrıca hakim tarafindan da onaylanması gerekmektedir. Hakimin ayrıca, çocukların durumuna ilişkin anlaşmanın onların yararına uygunluğunu da saptaması gerekir (Öztan, 2015, s. 698701). Dijital boşanmada ise, evrakların sisteme yüklenmiş ve anlaşmaların yapılmış olması boşanma kararının verilmesi açısından yeterlidir. Hakimin re'sen araştırma görevi bulunmamaktadır. Alman ve İsviçre hukukunda ise, Türk hukukundaki anlaşmalı boşanmaya benzer düzenlemeler yer almaktadır.

Hakim, boşanmayı talep eden tarafların ve çocukların menfaatlerini göz önünde tutarak aralarındaki anlaşma metninde gerekli gördüğü değişiklikleri yapabilir. Hakimin anlaşmanın içeriği konusunda yapacağı inceleme bir yerindelik denetimidir. Hakimin anlaşma metninde yaptığ düzenlemelerin taraflarca da kabulü halinde boşanmaya hükmolunur. Taraflarca önerilen değişiklik kabul edilmezse, davaya TMK m. 166/1-2 hükümlerine göre devam edilmesi gerekir (Gençcan, 2016, s. 347). Ancak TMK çerçevesinde, anlaşmalı boşanmada, boşanmaya karar verecek kişi sadece hakimdir. Yani, 
her ne kadar taraflar anlaşsa da, mutlaka mahkeme yoluyla davanın sonuçlanması gerekmektedir. Almanya'da son birkaç yıldır, mahkemeye başvurulmaksızın boşanma kararı verilmesine ilişkin görüşler tartışılmaktadır (Dutta, 2017, s. 51-60). İhtiyarî uyuşmazlık çözüm yollarından biri olan arabuluculuk müessesesi bir çok Avrupa ülkesinde aile arabuluculuğu şeklinde uygulanmaktadır. Bu şekilde, aslında mahkemelerde çözümlenmesi gereken birçok uyuşmazlık kısa ve ucuz bir maliyetle çözüme kavuşturulmaktadır.

TMK'ya göre hakim, tarafların ve şahitlerin beyanlarını dikkate alarak (Gençcan, 2017, s. 735; Yarg. 2. HD. 19.11.2012, E. 2012/23500, K. 2012/27564), somut olayı değerlendirerek, taraflar ve toplum için çiftin boşanmasının daha uygun olacağına kanaat getirirse, boşanmaya karar verecektir. Bir başka ifade ile, tarafların anlaşması hakim açısından bağlayıcı değildir ve hakimin mutlaka boşanmaya karar vermesini gerektirmez, hakim her zaman boşanmaya karar verip vermemekte serbesttir. Alman Medenî Kanunu'nda (BGB) ise, anlaşmalı boşanma dahi olsa eşlerin duruşmaya gelerek hakim önünde boşanmaya ilişkin beyanlarını açıklamaları gerekir.

Burada üzerinde durulması gereken bir başka nokta ise, TMK'ya göre, evlilikleri en az bir yıl sürmüş eşler anlaşmalı boşanma için başvurabilirler. Yani, burada anlaşmalı boşanma için minimum evli kalma süresi belirlenmiştir. Bunun nedeni ise, kanun koyucunun, en azından eşlerin henüz birbirini tanımadan boşanmalarının önüne geçmek istemesidir. Diğer Avrupa ülkelerinde ise genelde, boşanma kararı verilebilmesi için eşlerin belli süre ayrı kalma koşulu bulunmaktadır. Son dönemlerde bu süreler de kısalmıştır. Ancak örneğin, İsveç'te herhangi bir süre ayrı kalma şartı konmamıştır. Dijital boşanmaya başvuruda ise, eşlerin evli kaldığı süre açısından bir sınırlamaya gidilmemekle birlikte, ülkelerin millî hukuklarında eğer boşanmaya başvuru açısından belli süreler varsa, bunlar aynen korunmuştur. Bunun temel nedeni, dijital boşanmanın esasen usule ilişkin olmasındandır.

Hollanda ve Birleşik Krallık'ta uygulanmakla birlikte, Almanya, İsviçre ve diğer Avrupa ülkelerinde dijital boşanmaya gidilebilmesi için kanunda yeni bazı düzenlemelerin yapılması gerekir. Zira, 
dijital boşanmada taraflar bir araya gelmemekte, tamamen işlemler online olarak gerçekleştirilmektedir. Oysa, İsviçre ve Alman hukukunda tarafların mahkemeye gelmemesi halinde, hakimin davayı reddetmesi gerekir. Ancak, aile arabuluculuğu, adlî yargılama dışında bir usul izlediği için bu duruma istisna teşkil etmektedir.

\section{Sonuç}

Sonuç olarak, geleneksel boşanma kuralları teknolojik gelişmelerle birlikte değişime uğramıştır. Bu bağlamda, farklı ülkelerde dijital boşanmanın kuralları belirlenmeye başlanmış ve uygulamaya girmiştir. Son dönemlerde ortaya çıkan dijital boşanmaya ilişkin ilk gelişmeler Birleşik Krallık'ta ortaya çıkmış ve Hollanda'da da uygulanmaya başlanmıştır.

Dijital boşanma, klasik boşanma sebeplerini içine almakla birlikte, aslında boşanma işleminin usulü açısından farklılıklar yaratmaktadır. Yoksa biraz önce de üzerinde durulduğu gibi, boşanma sebeplerinde ve boşanmanın doğuracağı sonuçlarda herhangi bir değişiklik bulunmamaktadır. Geçtiğimiz sene Birleşik Krallık’ta başlayan bu pilot uygulama ile boşanmak isteyen çiftler için mevcut olan stresli durum en aza indirilmeye çalışılmış, özellikle boşanmak isteyen eşlerin birbirlerini görmemeleri ve birbirleriyle iletişimde bulunmamaları amaçlanmıştır. Bu nedenle, başvuruların ve usulî tüm işlemlerin online olarak sisteme yüklenmesi düşünülmüştür.

Dijital boşanmanın olumlu yanları olduğu gibi bazı olumsuzlukları da bulunmaktadır. Örneğin, dijital boşanmaya ilişkin tüm başvuruların doğrudan mahkemeye online olarak gönderilmesiyle başlayan süreç, tarafları fiziksel olarak aynı ortam içinde bir araya getirmemektedir. Bunun bir sonucu olarak, boşanma kararı da çok kısa bir sürede verilebilmektedir. Ancak bu durum, tarafların boşanma sonrasında bazen pişmanlık duyabilmelerine neden olabilmektedir.

Klasik boşanmalarda ise, boşanma süreci uzun sürdüğü için eşlerin bir kez daha düşünüp, olayları yeniden değerlendirmeleri mümkün olabilmektedir. Ayrıca, klasik boşanmalarda anlaşmalı boşanma dahi olsa, genellikle boşanma kararı vermeden önce hakimin 
tarafları dinlemesi gerekmektedir. Bu nedenle, hakim gerekçeleri yeterli görmezse, tarafların boşanmamasına karar verebilir veya velayet konusunda çocuğun yararına, tarafların isteği dışında hüküm verebilir.

Avrupa'da boşanmalarda uygulamada karar mercii mahkemelerdir ve hakimin takdir yetkisi kural olarak korunmuştur. Hollanda ve Birleşik Krallık'ta dijital boşanma uygulamaya girse de, diğer Avrupa ülkelerinde ve Türkiye'de uygulanabilmesi için teknik alt yapının hazırlanması ve buna uygun hukukî düzenlemelerin yapılması gerekmektedir. Bu çerçevede, her ne kadar dijital boşanma ile anlaşmalı boşanma arasında benzerlikler olsa da, tarafların sağlıklı karar verebilmesi ve boşanma sonrası pişmanlıkların önlemesi açısından, hakimin takdir yetkisinin muhafaza edilmesi önem taşımaktadır. Bununla birlikte, son yıllarda mahkemelerin yükünü azaltmak ve tarafları kısa sürede sonuca ulaştırmak amacıyla, birçok Avrupa ülkesinde, adli yargılamanın yanında ihtiyarî uyuşmazlık çözüm yollarından arabuluculuk müessesesine de sıklıkla başvurulmaktadır.

\section{Current Regulations on Digital Divorce: Examples from Different Countries}

Law adapts to the changing needs of society. The rapidly advancing technology and the growing internet necessitate equally rapid adjustments. In this age, it has become normal for law and technology to interact, especially concerning legal transactions. The digital age needs technology oriented legal doctrine. In recent years, some enacted legislations and legal practices are aimed to resolve uncertainties created by technological developments.

One such development is the execution of some family law related transactions via the internet. European countries have been exposed to such technological transformation, especially after undergoing intense changes in family structures and relations in recent decades.

Divorce laws reflect political and cultural aspects of their host nations and consequently are quite varied across Europe. 
Roughly, there are two camps in Europe, conservatives and reformists. After the 1970s, modernization of legal regulations facilitated the changing of divorce laws depending on local priorities and developments. The French reforms of 1975 reflected the growing pluralism of the wider society. The new regulations allowed contested and consensual divorce, in addition to unilateral divorce after six years of separation. The length and complexity of the legal divorce proceedings necessitated a further procedural amendment in 2004, which allowed for the courts to decide on a divorce in a single hearing.

Meanwhile in Italy, the first law of legal separation of spouses was promulgated in 1970 due to serious clashes between those for and against granting the right to divorce. In 1987, the divorce law was liberalized, permitting consensual divorce after three years of separation. Malta was the last European country to put into effect the legal means for couples to divorce after a referendum in 2011.

The Salazar regime in Portugal banned divorce for Catholics for 35 years. A reform in 1975 allowed divorces to take place, including those based on mutual consent. However, Portugal is also one of the few European countries that allow administrative divorce at the civil registry offices for couples who agree on all ancillary matters.

In the United Kingdom, the issue of divorce sparked a heated debate. The country in 1973 introduced a special procedure for uncontested cases. This special procedure, which allowed divorce to be granted without a court hearing, became the norm in 1977. However, liberals evaluated the process as too difficult while conservatives argued it as too lax, criticizing the process as "divorce by post." The Family Law Act agreed in 1996 resulted in a process that was not an improvement on the previous one but also made it longer and more difficult. Eventually, authorities decided to restore the 1973 procedure.

In 2004, the Commission on European Family (CEFL) brought together the best practices across Europe to formulate a 
nonbinding model set of laws under the name of the Principles of European Family Law. Mutual consent of spouses was explicitly made grounds for divorce of spouses in many European countries, including Turkey. The commission accepted the Swedish model of divorce, which allows divorce with no set period of reflection for spouses with no dependents.

It is natural for divorce laws in Europe to change in accordance with the changing needs of society. The latest development is online divorce, or in other words digital divorce. In the history of divorce laws in European countries, digital divorce can be seen as the modern day adaptation of the principle of mutual consent of spouses, including legal agreements on the guardianship over children and financial matters that have long been applied across Europe. The Netherlands and U.K. were the first in Europe to accept digital divorce as a legal procedure. In the U.K., divorce without a single court hearing is possible as long as the spouses agreed on separation. In digital divorce, spouses do not even need to meet, and instead can agree to divorce over the internet in a cheap and fast way. In most European countries, including Turkey, spouses can seek divorce when the two parties reach agreement on all ancillary matters to dissolve their marriage, but, at the end of the day, a judge's approval is needed. One exception is Portugal, where spouses can seek administrative divorce at the civil registry. This article will discuss and compare the legal developments concerning various divorce laws in European countries, with special focus on digital divorce and its consequences.

\section{Kaynakça/ References}

Akıntürk, T. (2006). Aile Hukuku. 10. B. İstanbul: Beta.

Akkaya, T.(2017). Medeni Usul Hukuku Bakımından Boşanma Davası. Ankara: Yetkin.

Carbonnier, J. (2002). Droit Civil, La famille, l'enfant, le couple, 21. B. France: Presses Universitaires de France P.U.F.

Boele-Woelki, K./Ferrand, F. (2017). Principles of European Family Law Regarding Property Relations between Spouses. Cambridge/UK: Interrentia. 
Dural, M./Öğüz, T./Gümüş, A. (2005). Türk Özel Hukuku. C. III, Aile Hukuku. İstanbul: Filiz.

Demirel İçöz, D.,Büberci, Gülen A. (2017). Boşanma Davaları. C.2. Ankara: Seçkin.

Detloff, N. (2015). Familienrecht, 31. B. München: C.H.Beck.

Dutta, A., Schwab, D., Henrich, D. (2017) Scheidung Ohne Gericht? Beitaege zum europischen familien und Erbrecht. Band 18, Bielefeld: Giesching.

Ercan, İ. (2000). Richter und Parteien im Scheidungsverfahren, Eine rechtvergleichendeStudie zum deutschen, schweizerischenund türkischen Recht. München: Herbert Utz.

Erdem, M. (2018). Aile Hukuku. Ankara: Seçkin.

Ertuğrul, N./Ertuğrul, T. (2011). Uygulamada Boşanma Davaları. Ankara.

Feyzioğlu, F. D. (1986). Aile Hukuku. 3. B. İstanbul: Filiz.

Hausheer, H., Walter, H.P. (2012). Berner Kommentar ZPO (Schweizerische Zivilprozessordnung). Bern: Staepfli.

Hawthorne, J., Jessop, J., Pryor, J., Richards, M. (2003). Supporting children through family change. York: Joseph Rowntree Foundation.

İkizler, M. (2018). Evlenmenin Hükümsüzlüğü. Ankara: Seçkin.

Gençcan, Ö. U. (2017). Boşanma Tazminat ve Nafaka Hukuku. 7. B. Ankara: Yetkin.

Gençcan, Ö. U. (2016). Aile Mahkemesi Davaları. 2. B. Ankara: Yetkin.

Gençcan, Ö. U. (2011). Aile Hukuku. Ankara: Yetkin.

Grosdidier, P. (2017). Digital Divorce. Texas Bar Journal, 80 Tex. B.J. 230, (April), 1-4.

Gümüş, M.A. (2008). Evliliğin Genel Hükümleri ve Mal Rejimleri. İstanbul: Seçkin.

Güneş Peschke, S. \& Peschke, L. (Ocak-Nisan 2013). Protection of the Mediatized Privacy in the Social Media: Aspects of the Legal Situation in Turkey and Germany. Gazi Universitesi Hukuk Fakültesi Dergisi, 17 (1-2), 857-883.

Kırmızı, M. (2018). Aile Hukuku Davaları. Ankara: Bilge.

Landers, J. (2013). How Social Media can effect your divorce? Forbes. https:// www.forbes.com/sites/jefflanders/2013/08/20/how-social-media-canaffect-your-divorce/\#1d05fcb735a3, Son erişim: 15.06.2018.

Lowrance, M. \& Hutul, P.J. (2013). Social Media in Divorce Proceedings. Family Lawyer Magazine. https:/familylawyermagazine.com/articles/ social-media-in-divorce-proceedings, Son erişim: 15.06.2018.

Oberhammer, P. \& Domej, T. \& Haas, U. (2014). Kurz Kommentaar, SweizerischeZivilprozessordnung. Basel: Helbing Lichtenhahn Verlag.

Oğuzman, K. \& Dural, M. (1998). Aile Hukuku. B. 2, İstanbul: Filiz. 
Özdemir, N. (2003). Türk-İsviçre Hukukunda Anlaşmalı Boşanma. İstanbul: Beta.

Özuğur, A. İ. (2013). Boşanma, Ayrllık ve Evlenmenin İptali Davaları. 5. B., Ankara: Seçkin.

Öztan, B. (2013). Medeni Hukukun Temel Kavramlarl. Ankara: Turhan.

Öztan B. (2015). Aile Hukuku. 6. B. Ankara: Turhan.

Öztürk, A. (2015). Aile Hukukunda Ayrllı. Ankara: Seçkin.

Parkinson, L. (2014). Family Mediation, Appropriate Dispute Resolution in a new family justice system. Bristol: Family Law.

Rechberger, W. H. \& Simotta, D. A. (2010). Grundgrissdes österrischen Zivilprozessrecht. 8. B, Viyana: Manz.

Scherpe, J. (2016). European Family Law. Volume II. The Changing Concept of Family Law and Challenges For Domestic Family Law. Glos: Elgar.

Scherpe, J. (2016). European Family Law. Volume III. Family law in European Perspective, Glos: Elgar.

Scherpe, J. M. (2016). European Family Law. Volume: IV. The Present and Future of European Family Law, Northampton: Elgar.

Schwarz, A. (1946). Aile Hukuku. B.2, İstanbul: İstanbul Üniversitesi Yayınları.

Stark, B. (2005). International Family Law. Burlington/USA: Routledge.

Tekinay, S.S. (1990). Türk Aile Hukuku. 7.B., İstanbul: Filiz.

Thompson, J. (2011). Family Law in Scotland. 6. B., West Sussex: Bloomsbury Publishing.

Ural, S.\&Karagülmez, A. (2003). Aile Mahkemelerinin Kuruluş, Görev ve Yargılama Usulleri. 2. B. Ankara: Seçkin.

Velidedeoğlu, H.V. (1965). Türk Medeni Hukuku, C.II, Aile Hukuku. 5. B., İstanbul: Nurgök Matbaası.

Vezzetti, V.C. (2016). New approaches to divorce with children: A problem of public health. Health Psychology Open, 3 (2), 1-13.

Welstead, M. (2012). Divorce In England And Wales: Time For Reform. The Denning Law Journal, 24 (1), 21-37.

Yıldırım, A. (2014). Türk Aile Hukuku. Ankara: Savaş. 